\title{
CULTURAL SUSTAINABILITY THROUGH COVID 19: A CASE STUDY OF THE FESTIVALS ON THE ISLAND OF RHODES
}

\author{
Dimitrios Matzanos ${ }^{1}$ and Yota Xanthacou ${ }^{2^{\star}}$ \\ ${ }^{1}$ Dr., Post Doctoral, University of Aegean, Greece, matzanos@aegean.gr \\ ${ }^{2}$ Professor, University of Aegena, Greece, xanthakou@rhodes.aegean.gr \\ ${ }^{*}$ Corresponding author
}

\begin{abstract}
Cultural heritage is one of the key elements of a region's identity and local culture can be an important asset in an effort to highlight and promote a region with the ultimate goal of sustainable development and prosperity of the local community.

Local festivals and celebrations contribute to reducing tensions, overcoming dividing lines, developing reciprocity and respect for diversity. They give participants the opportunity to create bonds of contact and communication, create a "sense of belonging", cross borders and dividing lines, fight social exclusion, are the right cohesive web for strong social cohesion. The role of local festivals and fests in the economic, social and cultural sustainability of communities has been highlighted in the international literature.
\end{abstract}

During the summer of 2020, all festivals and local celebrations throughout Greece were suspended due to the Covid pandemic 19.

The new coronavirus pandemic (COVID-19) appeared and spread in Greece from February 26, 2020 onwards. After the confirmation of the first three cases in Greece, on February 27, 2020, all the carnival events in the country were canceled and on March 10, it was decided to close all the educational structures, all the levels of the country. On March 13, the service of cafes, bars, museums, shopping malls, sports facilities and restaurants will be suspended and on March 16, all shops will be closed, while it was decided to suspend all functions of every denomination and religion. On July 132020 , it was decided to temporarily ban until July 31, the holding of festivals or other similar public open events of local or non-local character by private or non-private organizations. A new ministerial decision extends the ban from August 1 to August 31, 2020.

The present research aims to detect and record the views of representatives of cultural institutions and citizens of the island of Rhodes regarding the cancellation of all local celebrations and festivals in Greece due to the pandemic of Covid 19, as well as the consequences in the economic, social and cultural field in local communities.

It was a field research and the island of Rhodes in Greece was selected as a case study. It took place between October and November 2020, before the appearance of the second wave of the pandemic. Semistructured interviews were conducted. The sample was consisted of 30 representatives of cultural institutions and 40 citizens - residents of the villages of the island of Rhodes.

The results show that the representatives of the cultural institutions and the inhabitants of the villages express their frustration, dissatisfaction and anger, but it seems that they perceive and understand the new state of affairs and adapt to the new conditions. They admit that the festivals are detrimental to the health of the community, but point out the lack of communication and the cohesion of the social fabric on the island of Rhodes since the cancellation of the festivals. Regarding the effects that result from the cancellation of the 
festivals, the "economic" ones play a dominant role and in particular in different social groups: producers, merchants, musicians, singers, etc.

Finally, they consider that serious consequences arise from the deprivation of the "amusement" of entertainment and collectivism with consequent psychological problems.

The results of the research are considered important and satisfactory, as they demonstrated the need for preservation and sustainable development of festivals and folk festivals, highlighting their contribution to the economic, social and cultural development of local communities.

Keywords: Cultural Sustainability, Festivals, Covid 19.

\section{INTRODUCTION}

\subsection{Cultural Sustainability and Festivals}

Cultural heritage is one of the key elements of a region's identity and local culture can be an important asset in an effort to highlight and promote an area with the ultimate goal of sustainable development and prosperity of the local community (Deffner \& Metaxa, 2007).

Sustainable management of our cultural heritage is a task that requires special attention and sensitivity. The meeting of the past with the present, of the global with the local, of tradition with modernity can create new realities both in the field of art and social life. And it is no coincidence that everywhere, as a compensation for rapid globalization and cultural homogenization, there is a sharp shift towards exploring and reinterpreting the world of tradition and local cultures, towards the creation of a new system of values and a new cultural identity (Papavasileiou, 2017).

The festival is an important element of our cultural heritage. It is a living and modern tradition that connects the present with the past and the future. Its knowledge is passed down from generation to generation, while strengthening the sense of common identity and continuity. It is always connected with the landscape, nature and history. It is a unique opportunity to renew the bonds of "together belonging" to all residents of the local community (National Index of Intangible Cultural Heritage, 2016).

Local festivals and celebrations give participants the opportunity to create bonds of contact and communication, create a "sense of belonging", cross borders and dividing lines, fight social exclusion, are the right cohesive web for strong social cohesion (Pittas, 2013).

The involvement of the local community is essential in order to achieve sustainable development through the cultural identity of the place. Its involvement in all actions to achieve sustainable development, ensures mutual trust and certainty for the solution of problems at the local and not only level. Programming, planning and long-term community management are essential elements for a thriving local economy, based on sustainable development (Xanthacou et al., 2015).

The local community plays a key role in the sustainable development of the region, which plays an significant role in promoting the goals for the propulsion and utilization of cultural heritage. The coexistence and utilization of the elements of the natural environment of the local tradition and culture, can lead to the development of the area with respect and without re-burdening the local natural environment (Xanthacou et al., 2015).

The financial viability of the festivals implies the use of the available resources in an efficient and responsible way and ensures the fulfillment of all the financial obligations over time. The factors of economic viability can be: the return on investment of the festival, the local economy, the capacity of the local market, the innovation that the festival may present, the local development, the profit sharing, the business performance of the festival (Philips \& Philips, 2011).

Today, many local festivals and fairs have become an important area of development in the tourism industry. In the United Kingdom, in 2015, the events sector contributed 39.1 billion in direct revenue to the UK economy. Due to their territory and popularity, festivals and fests are of increasing interest to academics, with special invitations to research on their management and evaluation (Mair \& Whitford, 2013). 
The relationship between people and the festival is an interactive relationship and is based on mutual feedback. People visit the festivals to have fun and communicate with each other, respecting and following an ancient tradition. However, the festivals evolve and take shape over the years, depending on the daily conditions of the people who contribute to their realization, either as visitors or as residents of the local community that organized them (Matzanos et all., 2020).

Local festivals and celebrations contribute to reducing tensions, overcoming dividing lines, developing reciprocity and respect for diversity. They give participants the opportunity to create bonds of contact and communication, create a "sense of belonging", cross borders and dividing lines, fight social exclusion, are the right cohesive web for strong social cohesion (Pittas, 2013).

Local culture through an organized design can extract a specific identity of the place creating a driving force of development. The success of an organized project depends not only on government support, but also on the acceptance and active involvement of the local population. Even decision-making must involve the local community and give it the right to information (Tabakis, 2009).

The participation of the active citizen is important, as all political actions, rules, institutions and resources are issues of the local community, which has as its main priority the activation and participation of the citizen. The cultural dimension at the local level is considered a key element of development, the creation of sustainable communities and local vitality, as it is related to objects and media that inform, educate, sensitize and mobilize local populations (Bitsani, 2002 Tzamperis et al., 2015).

\subsection{Covid 19}

An outbreak of pneumonia has occurred in Wuhan City, Hubei Province, China. On January 9, 2020, the Chinese health authorities announced that this is a new strain of coronavirus (2019-nCoV). Coronaviruses are a group of viruses that usually cause respiratory infections of varying severity in humans and animals. It is estimated that about one third of human upper respiratory tract infections can be caused by coronaviruses.

The pandemic of the new coronavirus 2019-20 (COVID-19) appeared and spread in Greece from February 26, 2020 onwards. The majority of the cases that occurred in the first days were related to people who traveled to Italy, a major outbreak, and to a group of pilgrims who had traveled to Israel and Egypt, as well as contacts of these people. Health authorities recommend that travelers returning from affected areas or people who have come into contact with them remain under house arrest for 14 days, the maximum incubation period for the virus. At the end of January 2020, the Greek Ministry of Health designated thirteen basic and alternate reference hospitals per Health District equipped with a negative pressure chamber, to deal with cases of the virus in the country (Vagionis \& Leontidou, 2020).

After the confirmation of the first three cases in Greece, initially on February 27, 2020 all carnival events in the country were canceled and by March 10 there were a total of 89 cases in the country that were mainly related to travelers from Italy as well as a group of pilgrims who had traveled to Israel and Egypt and their contacts. The health and state authorities issued recommendations and instructions for the protection of the population, while the measures taken until then concerned the local level and included the closure of schools and the suspension of cultural and artistic events in the affected areas (especially llia, Achaia and Zakynthos) (Ministry of Health, 2020).

However, on March 10, due to the outbreak of the virus in various parts of the country and due to noncompliance with restraining measures by citizens, it was decided to close all educational structures, all levels, the country and then, on March 13 , the suspension of cafes, bars, museums, shopping malls, sports facilities and restaurants. On March 16, all commercial stores (National public health organization, available online: www.eody.gov.gr) closed, while it was decided to universally suspend all functions of any dogma and religion. Bakeries, supermarkets, pharmacies, private health services and some other businesses remained open. Since March 16, daily television updates have been introduced by the Ministry of Health on the evolution of the pandemic in Greece and the government's emergency decisions to deal with it, which stopped at the end of May but resumed in mid-July. The total cost of the measures announced by the government to support the economy, businesses and workers amounts to 24 billion euros, which corresponds to $14 \%$ of the country's GDP (Ministry of Health, 2020).

From 6 in the morning of March 23, significant restrictions were imposed on the movement and movement of citizens throughout the territory, with certain exceptions. On April 4, it was decided to extend the restrictions until April 27, and on April 23 it was announced to extend again until May 4. As of May 4, the government's plan for the gradual de-escalation of emergency measures, with the lifting of travel restrictions and the resumption of operations, was implemented. On 13 July 2020, it was decided to temporarily ban until 31 
July, the holding of festivals or other similar public open events of local or non-local character by private or non-private organizations. A new ministerial decision extends the ban from August 1 to August 31, 2020 (Vagionis \& Leontidou, 2020).

\section{MAIN PART}

\subsection{Research Method}

The present research, which is part of a wider research, aims to detect and record the views of representatives of cultural institutions and citizens of the island of Rhodes regarding the cancellation of all local festivals in Greece due to the pandemic of Covid 19, as well as and the economic, social and cultural implications of local communities.

It was a field research and the island of Rhodes in Greece was selected as a case study. It took place between October and November 2020, before the appearance of the second wave of the pandemic. Semistructured interviews were conducted. The sample was consisted of 30 representatives of cultural institutions and 40 citizens - residents of the villages of the island of Rhodes.

In the present study, the association of festivals and local collective holidays with the spread of the Covid 19 pandemic and its effects, constitutes the general framework of problematic, importantance and originality, giving special weight and focusing on the views of cultural associations and its citizens. of the island of Rhodes regarding whether the difficult and unprecedented conditions prevailing this year due to the COVID19 pandemic, affected the economic, social and cultural sustainability of the festivals.

This research was conducted exclusively by the researchers from October to November 2020. The semistructured interview was used as a methodological tool of the research, because each participant had enough initiative in formulating his answers, the researcher limited the interventions, but also took care to direct the subject to talk about issues that the purpose of the research required to be covered during the available time (Bell, 1997). It was sampled in terms of the institutions of cultural associations and citizens of the island of Rhodes (30 institutions and 40 citizens).

The interviews with all the institutions of the cultural associations and the citizens were conducted (after the telephone communication of the researcher with the institutions) in their homes. The questions followed a general written outline that served as a reminder, but based on the principles governing the semi-structured interview, each participant was free to focus on points of interest, according to their own judgment and experience. All interviews were transcribed using a simple tape recorder and then transcribed and transcribed.

After transcribing the interviews, we proceeded to analyze the content of the responses of representatives of cultural institutions and citizens and then categorize their responses into a limited number of independent categories. This was followed by the analysis of the research data of the interviews, the results were extracted and finally the conclusions were formulated.

\subsection{Description and Analysis of Results}

The survey includes a total of fourteen (14) questions. This article presents seven (7) questions that refer to the views of cultural associations and citizens of the island of Rhodes regarding the suspension of all festivals and collective celebrations due to a pandemic, as well as the economic, social and cultural implications. level.

From the elaboration of the answers, as they were recorded from the interviews, the following results emerge, which, in the context of the present work, cannot be presented and commented in detail, so only some indications are given and in relation to the research axis regarding the effects of pandemic cancellation of festivals on local communities.

When asked if any festivals were planned and implemented this year, $100.0 \%$ of respondents said that yes, they were designed but never implemented due to a pandemic.

The following question explores the views of representatives of cultural associations and citizens on the reactions to the cancellation of the festivals. The data of the answers show that $64.3 \%$ express frustration with the cancellation of the festivals, $21.4 \%$ express dissatisfaction and anger, while $14.3 \%$ of the respondents express understanding and adaptation to the new conditions.

In the next question, on whether they consider that the holding of festivals in the midst of a pandemic is detrimental to the health of the community, $94.3 \%$ of the sample state that the festivals are detrimental to the 
health of the community, while $5.7 \%$ of the sample state that if the hygiene rules are followed with the necessary distances then there will be no problem for the health of the community.

When asked what measures should be taken during the festivities to reduce the risk of spreading the pandemic, $82.9 \%$ of respondents say that no measures can be observed, $11.4 \%$ of the sample say that to observe the expected number of participants, while $5.7 \%$ state that each group should have fun separately and at a distance from the other groups.

When asked about the consequences of canceling the festivals, more than one answer was given, with the result that the total frequencies exceeded the sample size. The data show that $90.0 \%$ of the respondents state that the effects are economic, $58.6 \%$ state the deprivation of entertainment - amusement, $54.3 \%$ state the effects on the collectiveness of the community and the communication with the consequences psychological problems, while $31.4 \%$ indicate an impact on the cultural sustainability of the festivals.

In the next question, on how citizens express their dissatisfaction with the cancellation of the festivals, $54.3 \%$ of the sample state that the citizens express their dissatisfaction with discussions that usually end in protests, $30.0 \%$ state that express their dissatisfaction with anger and rage, while $15.7 \%$ state that they constantly turn to the organizers for whether a solution has been found to hold the festivities.

Finally, to the question about the main problems that will arise in the society of Rhodes this winter under the conditions of the pandemic, more than one answer was stated, with the result that the total frequencies exceed the sample size. The data show that $87.1 \%$ occupy the statements regarding the financial problems that will arise, $84.3 \%$ occupy the statements regarding the social problems, $74.3 \%$ occupy the statements for the psychological problems that will arise, $57.1 \%$ for the health problems, $54.3 \%$ for the communication and alienation problems between the members of the community, while $25.7 \%$ occupy the statements regarding the cultural problems that will arise.

\section{CONCLUSIONS - SUGGESTIONS}

The difficult and unprecedented conditions that prevail this year around the world due to the COVID-19 pandemic, very quickly seemed to affect the cultural activity of all countries. This resulted in the cancellation of all events in Greece. The effects and reactions of the citizens were varied.

Regarding the views of the bodies of cultural associations and the citizens of the island of Rhodes on whether the festivals and collective celebrations were planned and finally canceled due to a pandemic, all stated that they were canceled and that for the year 2020-2021 they are "sailing" in uncharted water. They claim that they have accepted the fact that it will be a difficult year for the clubs involved in organizing and holding the festivals. Also, hosting invitations were canceled that under normal circumstances (without the threat of a pandemic), a variety and quantity of collective events would take place that feed the communication and cohesion of the social web on the island of Rhodes and more widely with clubs in other areas.

The reactions of the participants in the festivals and the collective celebrations (according to the bodies of the associations and the citizens) range from frustration, dissatisfaction and anger to the understanding and adaptation to the new conditions. They argue that people need to have fun, be entertained and get in touch with their fellow villagers and especially with expatriates returning in the summer, in order to maintain a cohesive web for strong social cohesion.

By delving deeper into the themes of festivals and collective celebrations, they realize the value of these events. For the sectors of the associations and the citizens, apart from the economic, social, cultural, entertaining - communicative weight of the festivals, they function as a "meeting date" stable and expected for some social groups.

The majority of the organizations and the festivals admit that in the current conditions the festivals burden the health of the community. Of course, there are very few cases that claim that if the participants of the festival accept and follow the rules of hygiene with the necessary distances, then there will be absolutely no problem for the health of the community. Of course, the above was stated before the appearance of the second wave of the pandemic which was more intense.

Regarding the measures that must be taken during the festivities, in order to reduce the danger, the institutions and the citizens of the island of Rhodes, realize that no measure can be observed. There are some more optimistic who suggest that the required number of participants be observed, or even that each group should have fun separately from the other festival groups so that there is no overcrowding. 
Regarding the effects that result from the cancellation of the festivals, the "economic" ones play a dominant role and in fact in different social groups: producers, merchants, musicians, singers, etc. Serious consequences still result from the deprivation of fun, entertainment and collectivity with consequent psychological problems. They also stress the risk of limiting the cohesion of the community from the lack of communication that took place during the festivities. Finally, reference is made to the degradation of cultural sustainability by the cancellation of festivals which are a cultural element not only of local communities but also of the whole country.

Regarding the reactions of the citizens, the institutions and the surveyed citizens point out three types of reactions. Some resort to discussions that usually lead to resentment and protests, others get frustrated and angry, and there are citizens who constantly turn to the organizers if a solution has been found for the festivities and collective celebrations. Still, few express nuggets of suspicion stating that it is done on purpose. However, the majority of stakeholders and citizens acknowledge that this is done for the common good.

Finally, regarding the main problems that will arise in the society of Rhodes in the winter under the conditions of the pandemic, the majority of institutions and citizens declare the economic problems with increasing unemployment, the social problems follow as an increase of violence has been observed and of domestic violence, psychological problems and serious health problems. A smaller percentage state that there will be communication problems between community members and alienation. Finally, they state that there will be problems in relation to culture from the ban on holding any kind of events that maintain the cultural identity of the place.

In conclusion, it seems that the bodies of cultural associations and the citizens of the island of Rhodes believe that the cultural sustainability and sustainable development of local communities is affected by the Covid 19 pandemic both economically and socially and culturally.

Greece is one of the richest in the world in cultural tradition and culture. Festivals are also part of this tradition and culture. The spread of the Covid 19 pandemic canceled all cultural events, directly affecting the festivals.

In order to maintain cultural sustainability, local cultural associations should be active and their goals and roles should be redefined, remaining ready for their immediate involvement after the end of the pandemic.

Furthermore, for the preservation, promotion and utilization of the festivals, the participation of the education is considered necessary as well as the participation and the active involvement of the local communities that with their special characteristics will form the management framework of the cultural events.

The results of the research are considered important and satisfactory, as they demonstrated the need for preservation and sustainable development of festivals and folk festivals, highlighting their contribution to the economic, social and cultural development of local communities.

\section{REFERENCE LIST}

Bell, J. (1997). Methodological Design of Pedagogical and Social Research. Athens: Gutenberg (in Greek)

Bitsani, E. (2002). Culture and Local Society: local cultural development in Greece and the role of Local Government, 1980-2000. Doctoral Thesis, Panteion University, Panteion University Library, Athens

Deffner, A. \& Metaxas, Th. (2007). Place marketing, local identity, and cultural planning: The Cult Mark INTERREG IIIc project. Discussion Paper Series,13 (16): 367 -380. Volos: University of Thessaly

Mair, J., \& Whitford, M. (2013). An exploration of events research: Event topics, themes and emerging trends, International Journal of Events and Festival Management

Matzanos, D. \& Xanthacou, Y. (2020). Cultural sustainability and sustainable development: a case study of the Rhodes festivals, Proceedings of the 6th International Scientific Conference "Communication, information, information and education in late modernity", IAKE, Heraklion, 10-12 July 2020

National Index of Intangible Cultural Heritage of Greece (2016). The traditional festival of Syrrako. Retrieved on 18-12-2019 from http://ayla.culture.gr 
Papavasileiou, V. (2015). Sustainable Development and Education: A multidimensional relationship. Athens: Diadrasi. (in Greek)

Papavasileiou, V., Nikolaou, E., Xanthacou, Y., Xanthis, A., Matzanos, D. \& Kaila, M. (2018). Organization pedagogical use of the spaces in the sustainable kindergarten: views of preschool education graduate students. IJAEDU- International E-Journal of Advances in Education, Vol. IV, Issue 12, 245250, http://ijaedu.ocerintjournals.org /download/article-file/615354

Papavasileiou, V., Nikolaou, E., Xanthacou,Y. Papadomarkakis, I., Matzanos, D. \& Kaila, M. (2017). Student preschool teachers' views about the pedagogical context of sustainable kindergarten. Proceedings of INTCESS 2017 4th International Conference on Education and Social Sciences. Istanbul, Turkey, 6-8 February, 2017

Philips, P. P. \& Philips, J. J. (2011). The Green Scorecard. Measuring the return in investment in sustainability initiatives. Boston: Nicholas Brealey Publishing

Pittas, G. (2013). Festivals in the Aegean. V. B. Athens: Lambraki Journalistic Organization, S.A.

Tampakis, S. (2009). Protected Areas: Yesterday's and Today's Policies. In E. Manolas (ed.), (2009). Issues of Forestry and Management of Environment and Natural Resources 1st Volume: Introduction to Forestry and Environmental Science, Periodical Publication. Orestiada: Democritus University of Thrace, Department of Forestry and Environmental Management and Natural Resources.

Tzamperis, N., Matzanos, D. \& Papavasileiou, V. (2015). The formation of active citizens at the local level and its contribution to the promotion of sustainability. In Fokiali, P. \& Xanthis, A., Papavassiliou, V., Mogia, A. and Kaila, M. (Eds.), Locality and Sustainable Development. Athens: Interaction, pp. 593614.

Vagionis, N., \& Leontidou, L. (2020). Mediterranean cultural and settlement tourism: alternative forms as a way out of seasonality and vulnerability. Region \& Periphery, 10, 71-102.doi: https: //doi.org/10.12681/rp.25481

Xanthakou, G., Christodoulakis, P. \& Petavraki, Ch. (2015). Sustainability and Locality: The application of the principles of Bioclimatic Architecture and the utilization of RES in traditional settlements. The case of Mesanagros on the island of Rhodes. In Fokiali, P., Xanthi, A., Papavassiliou, V., Mogias, A. and Kaila, M. (Eds.), Locality and Sustainable Development. Athens: Diadrai, pp. 249-292. 